\title{
Sångerna som gav finlandssvensk identitet
}

Den nationalromantiska, lyriska sånggenre, som på Otto Anderssons initiativ skapades under 1900-talets första decennier, upplever nu en renässans. Sånger tillhörande denna genre utkommer i dag i nyarrangemang på CD-skivor och kassetter, nya sångarskaror upptäcker dem på nytt, de tas upp i sångkörernas och sångartisternas repertoarer och konserter anordnas där dessa visor står i fokus. Sångerna går vanligen under beteckningen "folkvisor" och många av dem som vänder sig till traditionsarkiven för att få tag på gamla visor har just dessa sånger i tankarna.

Ann-Mari Häggman redogör för denna sånggenres tillkomsthistoria och dess betydelse för den finlandssvenska identiteten.

\section{Folkvisorna som inte är folkvisor}

I en artikel Några synpunkter på folkvistraditionen i Svenskfinland (1970) påtalar visforskaren Alfhild Forslin det faktum att den stora allmänhetens kunskaper om vår folkmusiktradition är mycket bristfälliga. Som exempel nämner hon att Alexander Slottes "Plocka vill jag skogsviol" uppfattas som folkvisa:

För femton år sedan blev jag uppringd av Finlands rundradio, som önskade få ett föredrag om våra finlandssvenska folkvisor. Jag minns inte hur orden härvid föll sig, men av någon anledning nödgades jag påpeka, att "Plocka vill jag skogsviol" inte är någon folkvisa i egentlig mening. Då utbrast min interlokutör häpet: "Verkligen?! I så fall vet jag ingenting om folkvisor." 
Alfhild Forslin uttrycker sin besvikelse över att hon i sitt radioprogram inte heller lyckades i sitt upplysningsuppsåt. "I en recension lästes blott en besvikelse över, att vi inte tycks ha några egna visor här eftersom det mest är lån från andra länder" (Forslin 1970, 103).

Jag kan gott förstå såväl forskarens frustration som recensentens besvikelse över att våra folkvisor inte är våra egna. Forskaren, som ser hur motiv och impulser lånats och vandrat, har svårt att isolera den svenska versionen av en visa från motsvarande visa på tyska, engelska eller isländska. $\AA$ andra sidan har folkvisorna allt sedan 1800-talets mitt mer än någon annan diktart eller musikgenre fătt symbolisera det nationella, det egna landets och den egna folkgruppens kultur. Också inom den svensknationella rörelsen i Finland användes folkvisorna för att skapa en känsla av historisk, kulturell och språklig gemenskap bland de splittrade finlandssvenskarna. Men man nöjde sig inte bara med att lyfta fram och återuppliva visor som upptecknats ur folktraditionen. Med folkvisorna som förebild skapades en helt ny nationalromantisk diktning som tolkade tidens kultursyn och rådande ideologi.

\section{Nationalromantik och folkvisor}

När det nationella uppvaknandet i Finland fick sin början var Finland ett ryskt storfurstendöme. Bland såväl svenska som finska studenter i Helsingfors flammade sinnena högt för fosterlandet och för det finska språket. Ur denna jordmån föddes småningom också den rörelse som drev den svenska befolkningens intressen och som i sin fosterländskhet förenades med den finsknationella.

När Finland 1809 slets loss från Sverige, som det hade varit en del av i sjuhundra år, var svenskan många bygders språk. Den svenska kulturen var sedan sekler basen för landets förvaltning och rättssystem och hela den s.k. bildade klassens umgängesspråk var svenska. Under 1800-talet trängde finskan med majoritetens rätt ut svenskan som gällande språk i det ena sammanhanget efter det andra. Svenskan drevs in i en försvarsposition och i försvarsstriden mobiliserades det svenska språkets och det nordiska arvets stolta traditioner.

Romantikens och nationalismens intresse för folket och folkets forntid hade ju som bekant resulterat i ett ivrigt samlande av allmogens visor. I enlighet med tidens nationella anda intresserade man sig i Finland till en början uteslutande för den finska folkdiktningen. 1835 utkom Kalevala som övertygande lyfte fram det finska språket och dess möjligheter. Verket fick omedelbar återverkan inom litteratur, konst och musik.

Småningom började likväl röster höjas för att man också kunde tillvarata den svenska allmogens folkdiktning. Man betonade att de visor som i flera hundra år sjungits på svenska i Finland inte alltid överensstämde med dem som upptecknats i 


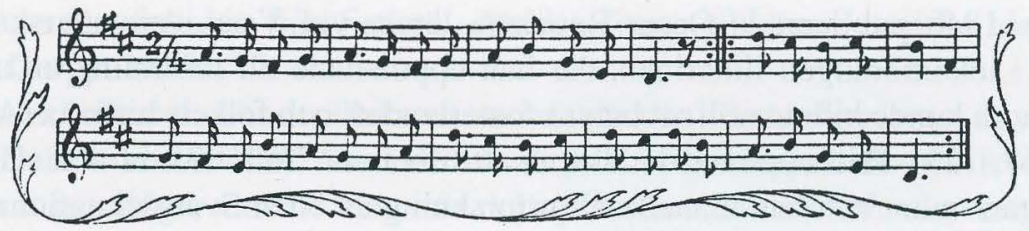

\title{
Plocka vill jag skogsviol.
}

\author{
Plocka vill jag skogsviol \\ och ljungens fina frans, \\ plocka, plocka famnen full \\ och binda till en krans. \\ Vintergrön och timje \\ minna mig om vännen min, \\ och många, många tankar jag \\ i kransen binder in.
}

Här är stigen, som vi gått

j söndagsstilla kväll.

Här vi suttit hand $i$ hand

på mossbelupen häll.

Är det ock en annan, som du givit har din hand, jag blir dig huld, du är dock min

i mina drömmars land. 
Sverige. 1848 publicerade Oscar Rancken, lärare vid Vasa elementarskola, ett upprop i lokaltidningen Ilmarinen, där han uppmanade till insamling av upplysningar som kunde bidraga till att belysa fosterlandets och folkets historia (Andersson 1967, 123). Han uppmanade läsarna att tillvarata "folkvisor af alla slag", sagor, sägner m.m. och han manade till utforskning av "den Svenska nationaliteten sådan den i Nyland, södra skärgårdsorterna och södra Österbotten bland allmogen visar sig". Och han tillägger: "Man behöfver ej frukta att det Finska skulle vanvårdas genom den uppmärksamhet, som egnas det Svenska elementet i landet, tvertom vinner det från denna sida en möjligtvis viktig belysning, ..." Det sista tillades förmodligen för att blidka de finsknationella.

Ranckens upprop är epokgörande inte bara för den finlandssvenska folkloreforskningen utan för hela den svenska nationalitetsrörelsen. Rancken var den första som talade om den svenska nationaliteten i Finland som en särskild befolkningsgrupp vid sidan av den finska, en befolkningsgrupp som bands ihop av ett gemensamt språk och en gemensam svensk kulturtradition (Andersson 1967, 126128).

Under 1800-talets senare del samlade skolelever, studenter och folkskollärare flitigt visor runtom i svenskbygderna. Visorna sammanfördes i vissamlingar som insändes till de initiativtagande institutionerna eller personerna (Rancken, Nyländska studentavdelningen, Svenska landsmålsföreningen, Kejserliga AlexandersUniversitetet, Svenska litteratursällskapet etc.) En del av visorna presenterades för allmänheten i uppsatser och föredrag eller framfördes vid konserter. Den första större utgåvan av upptecknade visor är Ernst Lagus utgåva Nyländska folkvisor (Nyland III och V. Helsingfors 1887 och 1893-1900). Författare och komponister började snart inse att man i visuppteckningarna hade ett rikt material att ösa ur. Runtom i Europa hade man långt tidigare hämtat inspiration i folkvisorna.

Den svenska befolkningen var utspridd längs kusterna och hade tidigare inte haft mycket samröre. Den svenska rörelsens ledare kom snart underfund med att folkvisorna kunde användas för att ena och stärka identiteten hos de splittrade svenskarna. Man kan lugnt säga att den svenska samlingsrörelsen - liksom för övrigt också den finska - kom att bäras upp av sång. Tydligast kom detta till uttryck vid sångfesterna, som blev stora kulturella och politiska manifestationer.

\section{Sångfesterna - kulturella och politiska manifestationer}

Sångfesternas rötter sträcker sig tillbaka till engelska körfester på 1600- och 1700talet. En mera nationellt folkbildande karaktär fick dessa fester på det tyska språkområdet i Centraleuropa fr.o.m. början av 1800-talet. Körer tillhörande den tyskbaltiska minoriteten anordnade sångfester i Reval fr.o.m. 1857 och i Riga fr.o.m. 1861, varpå idén även övertogs av befolkningsmajoriteten i dessa länder. Till Fin- 
land kom sångfestidén från Estland, där den första allmänna estniska sångfesten hölls i Dorpat 1869.

Finska folkupplysningssällskapet anordnade den första sångfesten i Jyväskylä 1884 (Dahlström 1991, 9). Avsikten var att folkupplysningssällskapets fester skulle vara tvåspråkiga, men de blev inte det i praktiken då den finlandssvenska uppslutningen var nästan obefintlig. Behovet av särskilda svenska samlingstillfällen gjorde sig snart gällande. Vissa finsknationalistiska uttalanden vid dessa sångfester - i Tammerfors 1888 uppmanades alla fosterlandets vänner att låta uppfostra sina barn på finska språket - påskyndade ytterligare den svenska väckelsen (Andersson 1947, 28).

Den första svenska sångfesten hölls på Svenska folkskolans vänners initiativ i Ekenäs 1891. Genom den öppnades vägen för de finlandssvenska musiksträvandena på bred folklig bas. Redan då fick festen den programuppläggning sångfesterna skulle behålla i över hundra år. De medverkande fördelade sig på hornkapell, blandade körer, manskörer och kvinnokörer, senare tillkom stråkorkestrar, ungdomskörer, spelmanslag etc. Repertoarens tyngdpunkt låg på psalmer och kompositioner i nationalromantisk anda. Vid denna första fest fanns endast tre folkvisor med på programmet. Deras andel skulle med tiden växa märkbart.

Musikrörelsen kom att få en genomgripande betydelse inte bara för det nationella medvetandet utan också för det allmänna folkbildningsarbetet. Otto Andersson framhåller att den finlandssvenska musikrörelsen bars framåt av flera grundidéer: fosterländskhet, svenskfinländsk samlingssträvan, musikalisk väckelsetanke och bildningsentusiasm (Andersson 1947, 11). Sångkörer, främst blandade körer bildades runtom i bygderna och leddes av folkskollärare som fick särskild handledning på detta område. 1947 kunde Otto Andersson konstatera: "Intet nordiskt folk, ja, ingen större folkgrupp har procentuellt uppställt så stora sångarskaror som Finlands svenskar" (Andersson 1947, 7).

Under seklets första decennier mötte sångfesterna motstånd från de ryska makthavarnas sida. Sångfesterna var de största finlandssvenska samlingarna, de viktigaste nationella och kulturella händelserna. Högstämda festtal hölls av den tidens politiska ledare. Det politiska klimatet vid denna tid kom bl.a. till synes i att man överhuvudtaget inte fick tillstånd att hålla den svenska sångfest som planerats för år 1901 (Andersson 1947, 113) och vid sångfesten i Vasa 1912 avbröts festtalaren, lantdagsmannen Julius Sundblom, av polismästare Fedoroff. Publiken reagerade med att sjunga "Modermålets sång" (Andersson 1947, 183-184).

Folkbildningen och spridandet av kännedom om den svenska folkkulturen i Finland kom att bli en av de bärande linjerna i arbetet för svenskheten i Finland. För finlandssvenskarnas del kan man peka på 1900-talets första decennium som massrörelsens tid (Kummel 1994, 159-160). I denna rörelse kom Otto Andersson och Föreningen Brage att spela en central roll. 


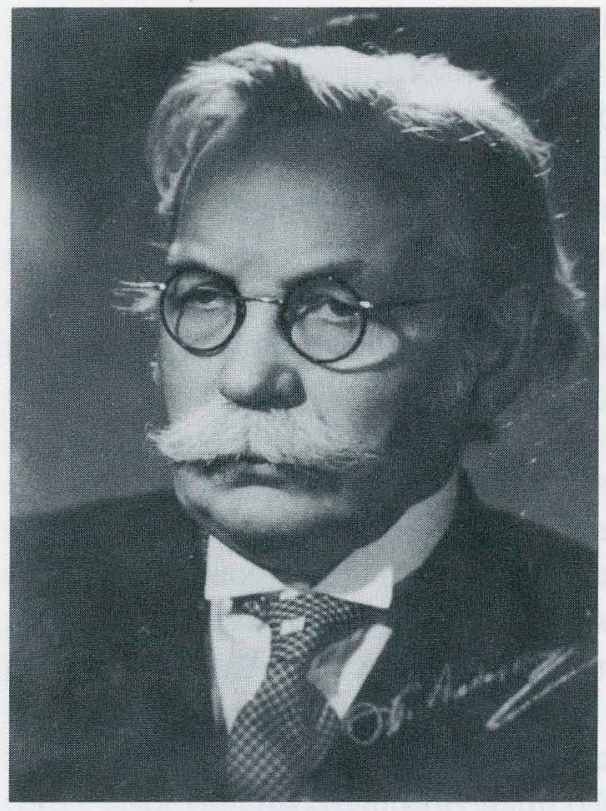

Otto Andersson 1879-1969. Finlands svenska folkmusikinstitut.

\section{Otto Andersson och Föreningen Brage}

Otto Andersson (1879-1969) hade vuxit upp i ett bondehem på Vårdö, Åland. Vad skolgången beträffar följde han till en början det traditionella mönstret. Han genomgick folkskola och inskrevs 1895 i Ålands folkhögskola i Jomala. Eftersom han hade anlag för musik sändes han till Klockare-orgelnistskolan i Åbo, där han skrevs in 1896. 1897 började han också avtjäna sin värnplikt vid Åbo skarpskyttebataljons musikkår. Vid den finlandssvenska musikfesten i Åbo 1897 deltog han som tenorsångare i Arbetets Vänners i Mariehamn sångkör. År 1900, efter fyra års studier, avlade Otto Andersson kantor-organistexamen, varefter han sökte sig till Helsingfors musikinstitut för fortsatta studier. Men han avbröt musikstudierna 1905, då andra intressen hade fångat hans uppmärksamhet. Han var vid denna tid ledare för Arbetets Vänners i Sörnäs sångkör, han var en av initiativtagarna till tidskriften Finsk musikrevy vars första nummer utkom i januari 1905, han var aktiv inom Svenska folkskolans vänners musikutskott och som litteratursällskapets stipendiat tecknade han upp folkmelodier.

Otto Andersson var således vid denna tid den praktiskt utövande musikern. När han efter en insamlingsresa till Österbotten 1904 inlämnade sitt material till litteratursällskapet hade han redan börjat fundera på att i sin musikverksamhet dra nytta av det insamlade materialet. Liksom den tidens upptecknare överlag var han övertygad om att landsbygdens musikliv höll på att utarmas, att de gamla visorna 
inom kort helt skulle försvinna och att dragspelet med sin lätta repertoar skulle ta död på den traditionella spelmansmusiken. Därför fick de upptecknade melodierna inte bli bortglömda och bara gömmas i arkiven. De skulle sjungas och spelas. Den plattform han behövde för ett sådant kulturprogram fick han i Föreningen Brage, som på hans initiativ grundades 1906. Föreningens uppgift blev att tillvarata och återuppliva yttringar av finlandssvensk folkkultur såsom folkmusik, folkdräkter och folkdans. Genom Brage kunde Otto Andersson basunera ut sitt budskap om de gamla folkmelodiernas stora skönhetsvärden och om vikten att hålla dem vid liv.

Otto Anderssons och Föreningen Brages verksamhet låg i tiden. Liknande strävanden förekom på finskt håll och $\mathrm{i}$ andra länder. Hos oss hade de fått sin början $\mathrm{i}$ olika sammanslutningar under 1800-talets senare del: i studentnationerna, Svenska folkskolans vänner, landsmålsföreningen, fornminnesföreningen, inom sång- och musikrörelsen, ungdomsrörelsen och nykterhetsrörelsen. Allt detta var Otto Andersson välbekant. I Brage lyckades han sammanföra idéer som han fångat upp på olika håll och fick möjlighet att tillämpa dem på det sätt han fann riktigt. Han blev en av galjonsfigurerna för svenskhetsrörelsen och den stora ledaren för det folkliga musiklivet.

Omedelbart efter det Brage inlett sin verksamhet tog Otto Andersson initiativ till en blandad kör. Eftersom det redan existerade en betydande finlandssvensk folkviserepertoar i goda körsatser kunde han omedelbart sammanställa kompletta program på folkmusikalisk bas. 1875 hade Otto Anderssons lärare vid musikinstitutet, Martin Wegelius (1846-1906), som den första arrangerat en finlandssvensk folkvisa, och den följdes av fler. Han uppmuntrade sina kollegor och elever att arrangera folkvisor; på 1890-talet gjorde Karl Flodin (1858-1925) och Karl Ekman (1858-1917) flera arrangemang - vardera hade som litteratursällskapets stipendiater tecknat upp visor i Åboland och på Åland. Som kördirigent och medlem av SFV:s musikutskott hade Otto Andersson kommit i så gott som daglig kontakt med dessa arrangemang.

Otto Anderssons stora genombrott som folkvisarrangör kom 1907 i och med uppförandet av Österbottniskt bondbröllop, Brages stora paradnummer genom tiderna. Det blev ett allkonstverk i sju tablåer, där folkliga visor, dansmelodier och danser sammanfogades till en helhet, sammanbunda av en text bestående av dialoger och monologer på Petalaxdialekt skrivna av "en gammal landsmålare" dvs. pastorn och lantdagsmannen A. R. Hedberg. Uruppförandet ägde rum vid en soaré i Societetshusets festsal i Helsingfors söndagen den 24 november 1907. Spelmanslåtarna, som framfördes av stråkorkester, hade arrangerats av V. Novácek. Dekorationerna som återgav interiörer och byar från det svenska Österbotten hade målats av Carl Bengts (BrÅ 1907, 9-10). Bondbröllopsidén och Brages bondbröllop har under decenniernas lopp tagits upp av ungdoms- och hembygdsföreningar runtom i svenskbygderna och framförts i varierande former. 
Idén till att man skulle skriva nya texter till gamla melodier fick Otto Andersson också under sina uppteckningsresor i Österbotten.

I början av mina resor för upptecknandet av folkmelodier för Svenska litteratursällskapets räkning (1902) lade jag märke till dels att somliga av de gamla polskorna åtföljdes av korta textstumpar - fragment eller rester av längre visor -, dels att en del av de österbottniska folkskalderna, "PaliMaja", Björkback-Hans (Hans Björk) m.fl. använt folkmelodier eller koraler för sina lyckönskningar och andra bröllopsdikter. Dessutom tycktes vissa spelmanslåtar äga lika goda tonala förutsättningar som många melodier som blivit ordsatta av skalder på förut nämnt sätt (Andersson 1969, 14).

Men långt tidigare under sin skoltid på Åland och i sångkören i Mariehamn hade han kommit i kontakt med dikter till folkmelodier. Han skriver därom i en uppsats "När spelmanslåten blev dikt", 1969.

Jag blev tidigt upplyst om att "Näckens polska" var diktad av A. A. Afzelius till en svensk bondpolska. Likaså var det allmänt bekant, att Sveriges nationalsång "Du gamla, du fria, du fjällhöga nord" sjöngs på en gammal balladmelodi. Under min elevtid i Ålands folkhögskola sjöng vi mycket Frans Österbloms hembygdssång "Jag älskar min hembygd vid svallande hav", diktad till samma melodi. - Längre fram lärde jag mig många svenska sånger, som var diktade till folkmelodier: "Vårvindar friska, leka och viska" av Euphrosyne (Julia Christina Svärdström), "Stunden bortilar men icke min smärta" av P. H. Lind, "O tysta ensamhet" av J. O. Wallin, "Ute blåser sommarvind" och "Förgäves uppå stigen" av S. J. Hedborn m.fl. Mästaren bland de skalder som utnyttjat folkmusiken på detta sätt i sitt skaldskap var naturligtvis C. M. Bellman. Han hade icke blott stimulerats av folkmusikens ofantliga rikedom utan även ordsatt flera visor och danslåtar än någon annan skald (Andersson 1969, 13).

Bland de melodier Otto Andersson upptecknat började han välja ut sådana, som föreföll lämpliga för ordsättning. Han försökte sig själv också på att efter känd modell skriva text till någon melodi, men då han inte blev nöjd med resultatet fann han för gott att anlita poetiskt begåvade personer i sin vänkrets, i första hand inom Bragekretsen. De nya visor som på detta sätt tillkom har ofta fått gå under beteckningen "Bragevisorna". 


\section{Visdiktarna}

Bakom den nya Bragelyriken stod triumviratet Otto Andersson, Alexander Slotte och Ernst V. Knape. Otto Andersson hade hoppats på fler poetiska medarbetare. I sin tillbakablick år 1969 skriver han:

Jag hade rätt när jag gissade att mina vänner Ernst V. Knape och Alexander Slotte skulle bejaka min anhållan om diktarhjälp. En tredje medarbetare fick jag senare i Jonatan Reuter, som vid mitt besök lovade dikta nya ord till en östnyländsk bröllopslåt, som jag hade tecknat upp med ett kort ordfragment: "Muntraste druva, din skål vill jag dricka". Däremot fick jag nekande svar från Jakob Tegengren. Han ansåg sig icke vara tillräckligt musikalisk för att våga sig på den föreslagna uppgiften. - Ingen framgång hade jag heller hos Hjalmar Procopé, som jag

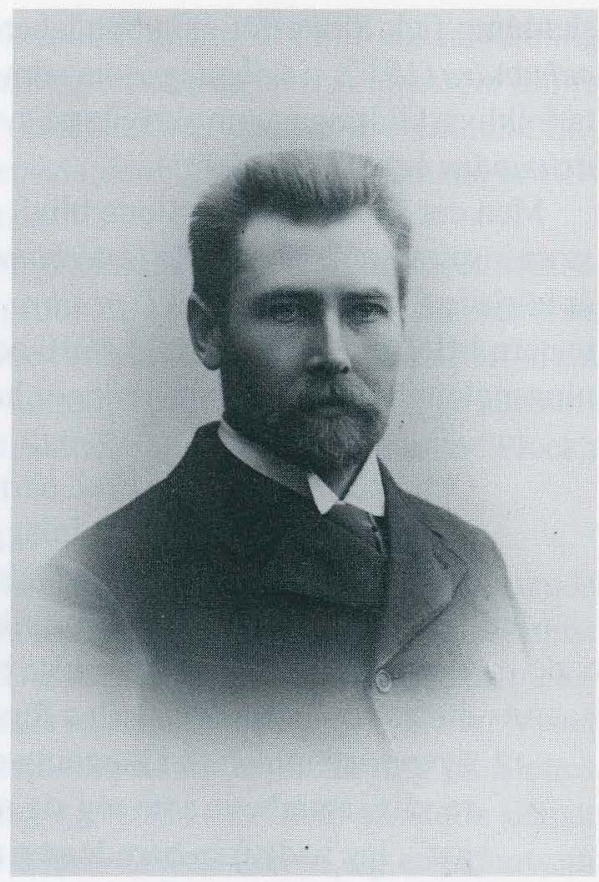

Alexander Slotte 1861-1927. Museiverket. också personligen framförde min anhållan till (Andersson 1969, 15).

Alexander Slotte (1861-1927) var född och uppvuxen i Nedervetil som son till lantdagsmannen, talmannen i bondeståndet och häradsdomaren Carl Johan Slotte (1827-1903). Alexander verkade som folkskollärare vid Helsingfors skolor från 1888. Under åren 1890-1907 var han samtidigt litteratur- och teaterkritiker vid Hufvudstadsbladet. Han var hängivet intresserad av teater; han hade studerat scenkonst i Danmark och Tyskland och var en av de drivande krafterna bakom Folkteatern i Helsingfors 1902-1904. När han blev aktiv inom Föreningen Brage innehade han befattningen som sekreterare vid Finlands allmänna slöjdförening.

Slotte hade anslutit sig till Föreningen Brage redan 1907. I två decennier var han en hängiven brageit, en stor del av denna tid som styrelseledamot. Han deltog gärna i Brages tillställningar och framförde vid olika tillfällen bygdemålsberättelser (se t.ex. BrÅ 1910, 3). Han engagerade sig varmt i Brages dramatiska verksamhet. När Brage 1909 utlyst en dramatisk pristävlan deltog Slotte under pseudonymen Sebastian Friis med folkpjäsen "Nej ta hålen nan målar min stugå rö!" som var avfattad på Gamlakarlebymål. Pjäsen inövades av Slotte "som själv på ett utmärkt sätt kreerade huvudrollen" (BrÅ 1909, 5). När Brages dramatiska verksamhet organiserades 1914 blev Slotte regissör för den dramatiska sektionen. Stor upp- 
skattning fick Slotte för sina bygdeberättelser från Österbotten. Med Karlebybor och andra (1912) slog han igenom som berättare. Den har ansetts var en av de bästa folklivsskildringar som skrivits på svenska i Finland. Därefter kom Solskensfolk och andra berättelser (1923).

Men det är som lyriker Slotte blivit mest känd och där var Otto Andersson den stora inspiratören. 1907 hade Österbottniskt bondbröllop haft premiär och följande år började Slotte arbeta med Den stora islossningen som hade premiär på Svenska teatern i Helsingfors den 15.11.1910 och för vilken han skrev nio sånger. I en tidningspolemik med K. Bruhn redogör han själv för tillkomsten av dessa dikter:

Och i början av detta sekel, närmare bestämt 1908, skrevs Den stora islossningen, där det gällde att inlägga lyriska partier i folkvisans ton. För pjesens uppförande skrev jag då självmant - utan någon som helst uppmaning - nio dikter, dels direkt till folkmelodier, dels för att tonsättas. Det var då Otto Andersson vid den första bekantskapen med dessa dikter kom mig till mötes med sin stora, varma förståelse. Det var då vi funno varandra, funno överensstämmelsen i läggning och intressen. Ur detta flöt sedan utan vidare vårt samarbete, som tog sig närmast uttryck i "Toner från stugor och stigar". Jag hade från barndomen uppbevarat i minnet en stor del folkmelodier. Men förrådet räckte icke till för vad jag behövde. Otto Andersson upplät då sitt rika förråd av melodiskatter, som han samlat i olika delar av Svensk-Finland. Han blev tillika den första välvilliga lyssnaren till visorna och sångerna. Från honom kom det första uppmuntrande gensvaret - som naturligt var på grund av hans djupa musikteoretiska insikter - den rådande hjälpen, då den behövdes. Han blev genom sina ypperliga arrangemang och sin utmärkta Bragekör den, som bar alstren vidare efter hand som de föddes (Vbl 7.7.1921)

Samarbetet mellan Otto Andersson och Alexander Slotte resulterade under de närmast följande åren i några av de verkliga pärlorna på den lyriska visans område. Också Ernst V. Knape engagerades av Otto Andersson vid denna tid för att skriva poesi till folkmelodier.

Ernst V. Knape (1873-1929) var född i Gamlakarleby, studerade medicin i Helsingfors, blev med. och kir. dr 1902 och var under tiden 1902-1908 anställd som stadsläkare i Nykarleby och därefter i Gamlakarleby. Från 1912 var han även docent i oftalmologi vid Helsingfors universitet. Han debuterade 1907 med diktsamlingen Akvareller, som följdes av flera andra. Näst dikterna till folkmelodier har hans novellsamling Österbottningar (1916), i vilken han skarpögt skildrar den österbottniska befolkningens förhållanden, väckt den positivaste responsen.

Otto Andersson var nyckelpersonen vid tillkomsten av de nya sångerna. Han 
valde inte bara melodier. Han uttryckte också ofta önskemål om i vilken riktning texten kunde gå. När en text var färdig samlades ofta dessa tre - Andersson, Slotte och Knape - för att tillsammans ta del av resultatet och diskutera eventuella finslipningar. Därefter arrangerade Otto Andersson den nya visan för blandad kör eller för solosång till pianoackompanjemang.

Otto Andersson har påpekat att det var en grannlaga uppgift att förse rätt författare med rätt melodi. Någon gång uppstod problem - som när han överlämnade en av de polskor han upptecknat efter spelmannen Johan Johansson Bränn i Purmo till Knape. Knape lyckades inte få "någon inre kontakt" med den melodin och återsände den till Otto Andersson, som gav den åt Slotte. Till den diktade Slotte "Plocka vill jag skogsviol".

När de båda diktarna senare träffades hos mig, där jag efter hand brukade sjunga deras nya sånger till de gamla melodierna, blev Knape stormförtjust i Slottes visa och yrkade bestämt på, att också han skulle få ordsätta melodin, eftersom den först hade sänts till honom. Slotte protesterade. Visan sjöngs på nytt. Jag kunde naturligtvis inte annat än ställa mig på Slottes sida. Knape hade ju återsänt melodin; jag tyckte dessutom att Slotte skapat en fin orddräkt för Bränns Purmo-melodi. Diskussionen tog en skämtsam vändning när Knape sade: "Jag köper melodin! Hur mycket vill du ha för den?" Detta förslag blev självfallet tillbakavisat (Andersson 1969, 15-16).

\section{Dikterna}

Den 29 november 1913 utkom Toner från stugor och stigar i tryck, ett litet dikthäfte till formatet endast 47 sidor, lagom till Brages soaré i Societetshusets festsal. I häftet ingår femton dikter till folkmelodier, nio är skrivna av Slotte, fem av Knape och en av Jonatan Reuter. Den lyrik som ingår i detta lilla dikthäfte intar en framskjuten plats i Svenskfinlands lyrik och knappast har någon senare diktsamling haft lika stor betydelse på ett brett folkligt plan.

Enligt Otto Andersson bär Slottes lyrik "den fullödiga konstnärlighetens prägel", den är "hembygdslyrik i detta ords bästa bemärkelse".

Inte bara därför att den i så hög grad är skriven till folkmelodier, utan framför allt därför, att den kväller fram ur den svenska folksjälen, vars skiftande nyanser, skuggor och dagrar, syner och föreställningar i denna diktning få ett så äkta och helgjutet uttryck (Andersson 1927).

Hembygdsdikten framom andra är "Slumrande toner". I denna nationalromantiska hymn förliknas hembygdsdiktningen vid en forneld, som genom tiderna skall 
lysa vår gärning och vägen till hemmet, vårt väsens källa. Sången skapades som en lystringssång för Föreningen Brage och texten är en poetisk omarbetning av Brages stadgar. Melodin är en skålmarsch från Karleby, som spelades när brudparet vid bröllopet tog avsked av sina vänner bland ungdomen. Läraren Henrik Ståhl tecknade upp melodin 1906-07. Otto Andersson hade fattat tycke för melodin och försökte själv skriva ord till den, men lyckades inte tillräckligt bra, ansåg han, och gav den till Slotte.

När tanken på att åstadkomma dikter till våra folkmelodier väcktes, önskade jag att först och främst leta upp en melodi som kunde läggas till grund för en lystringssång för föreningen Brage. Medan jag förgäves sökte i mina samlingar erbjöd Henrik Ståhl en melodi, som jag fann mycket lämplig. Jag gjorde flera försök att skriva ett par strofer till visan - jag hade Richard Dybeck i minnet - men misslyckades och gav då melodin åt Alexander Slotte med uttrycklig anhållan, att han skulle skriva lystringssången, vilket han hastigt gjorde med känd framgång (Andersson 1969, 18).

"Slumrande toner" sjöngs första gången vid Brages samkväm 27 oktober 1912. Den mottogs med entusiasm av brageiterna. Den 2 december uppträdde kören med den vid en konsert i Helsingfors universitets solennitetssal. Den slog genast an och uppmärksammades av tidningspressen (Nya pressen 28.10.1912). Vid detta tillfälle sjöngs den först av kören, sedan unisont.

I enlighet med Brages strävan uppmanar texten till vård av det forntida kulturarvet. Det måste återupplivas och föras vidare till kommande generationer. I denna - liksom i många av Slottes alster ses det förgångna som en idyll. En liten lutande, numera övergiven stuga under en rönn, där brasan en gång flammat och spinnrocken surrat. Dessa minnen är viktiga, hemmets plats är helig, säger Slotte. Vi skall väcka minnena och de skall lysa vår gärning och de skall föra våra söner hem till fädernas gård igen.

Tankegången är inte unik. Vi finner samma retorik i liknande diktning på annat håll vid denna tid. När texten läses skilt för sig förefaller den i dag nästan patetisk: fornelden skall flamma, vi skall lyssna till röster ur gravarnas dunkel, vi skall hörsamma fädernas budskap, sången vittnar om jubel och kvalsång från de hänsovnas strid. Lars Huldén skriver: "Orden är högstämda, nästan till bristningsgränsen". Huldén tolkar innehållet på följande sätt:

Toner och röster från en gången tid manas att vakna och förkunna ett uppbyggande budskap, med dess tänkta kvaliteter, till en mottaglig nutid. Det gäller att gå in i minnenas, traditionens heliga rum, gestaltad som en lutande stuga under en rönn, och få det att leva upp igen (Huldén 1990, 137). 
Vi ser likheten med Frans Österbloms populära hembygdssång "Jag älskar min hembygd vid svallande hav" (publicerad i SFV Kal. 1899). Den talar om "minnesrik", "fädernas aska", "hjältedåd", "frihetskärlek", "stam", "modersmål", "fädernebygd" och "fädrens arf och grifter".

Slottes dikt visar tydlig påverkan från den visgenre som forskarna kallar "den medeltida balladen". Han använder gammal adjektivböjning på samma sätt som balladen i "vänan lid", "ljudlösan ro" och subjektsomtagning i "minnena de sova". Omtagningen av de två sista versraderna i varje strof fungerar som ett slags omkväde (Huldén 1990, 136). Medvetet använder han ett ålderdomligt och högtidligt språk för att därmed markera kontakten till det förgångna: "Vaknen alla, höjen Eder!", "I bringen till söner..."

En ännu tydligare balladefterbildning finner vi i Slottes dikt "Jungfrun träder fram på riddarsalens golv". Här har Slotte låtit sig inspireras av en menuett från Oravais kallad "Gammel Torsin". Vid sångfesten i Helsingfors 1907 sjöngs melodin för Otto Andersson av systrarna Anna och Mathilda (Jakobsson) Jusslin. Andersson tog med melodin i Österbottniskt bondbröllop, där Slotte kom i kontakt med den och skrev sin dramatiska text. Här kommer Slottes forntidssvärmeri tydligt fram, liksom i flera av hans dramer. Den framfördes också som musikaliskdramatisk tablå.

\section{"GAMMEL TORSIN"}

Öb. OR: Anna o. Mathilda Jakobsson

Egen samling. O. A.
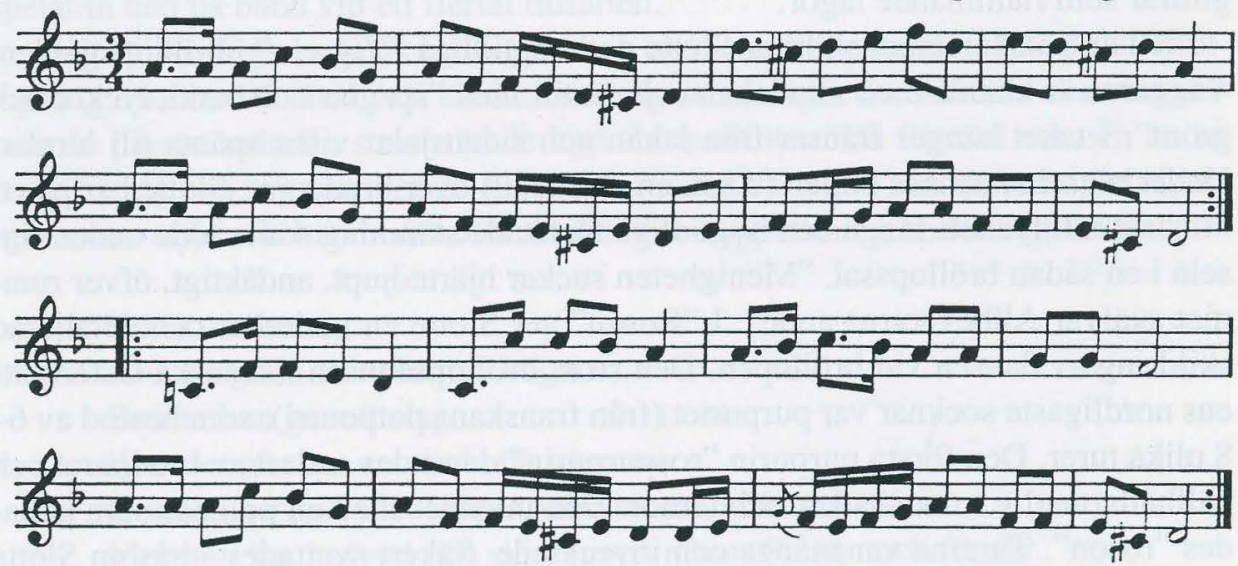

Menuetten "Gammel Torsin" som lades till grund för "Jungfrun träder fram". Finlands svenska folkdiktning VIA 1 . 
Till det fräschaste i Slottes diktning hör hans folkdiktsskildringar i poetisk form, bland vilka de tio dikter som ingår i "Bröllopssvit" intar rangplatsen. Den uppfördes första gången vid ett Bragesamkväm den 20 november 1915. Den 13 mars 1916 framfördes den vid en musikalisk-dramatisk soaré på Svenska teatern, där sviten enligt Hufvudstadsbladet gav "ett synnerligen förmånligt helhetsintryck" (Hbl 17.3.1916). Ett prydligt grått häfte i vilket dikterna ingick såldes vid samma tillfälle - vilket visar hur skicklig marknadsföringen av Brageprodukterna var. Slotte skildrar ett bröllop i sin hembygd, Nedervetil. Humoristiskt, fyndigt och poetiskt verkningsfullt beskrivs bröllopets olika skeden från gästernas ankomst till tredje dagens avslutning. Det är en folklivsskildring som är målad med färgstarka och tydliga penseldrag, en miljöskildring som i många stycken närmar sig Bellmans sätt att skildra begivenheter i sin omgivning.

Upptakt utgör den muntra marschen "Gästerna samlas". Texten är skriven till en brudmarsch, som varit allmän och som fortfarande spelas på bröllop i trakten när gästerna tas emot (på finska går den under beteckningen "Tulopeli"). Bröllopsgästernas antal var i början av seklet stort - ett normalstort bröllop hade några hundra gäster men det har förekommit bröllop med över 1000 deltagare. Storbönderna befäste sin ställning i närsamhället genom att bjuda på det bästa gården förmådde och det blev ett överdåd i fråga om mat och dryck. Med häst och kärra anlände prominenta gäster till bröllopsgården där de hälsades välkomna av spelmännens musik. "Brudefärden" skildrar brudens ankomst till bröllopsgården. Bruden kläddes vanligen i en annan gård och hämtades under stor högtidlighet och brudmarschens toner till bröllopsgården. Slotte skildrar ett s.k. kronbröllop där bruden bär den stora "guldkronan" vilken enligt Slotte i dikten "Brudefärden" glittrar som flammande lågor.

Till en polskemelodi skildrar Slotte den högtidliga "Vigseln" i bröllopsgården. Väggarna är klädda med vita lakan och därtill med "speglar och band, lyckor och grönt”. I taket hänger fransar från lakan och sidensjalar vilka spänts till himlar. Under vigseln spännes pällen (d.v.s. en sidensjal) över brudparet. Slotte har på ett utmärkt sätt lyckats fånga den högtidliga förtätade stämning som rådde under vigseln i en sådan bröllopssal. "Menigheten suckar hjärtedjupt, andäktigt, öfver rummet sväfvar Allbevararns ande". I "Rosan" ger Slotte en underbar och detaljerad skildring av dansen vid bröllopen. Den stora bröllopsdansen i svenska Österbottens nordligaste socknar var purpuriet (från franskans potpourri), som bestod av 68 olika turer. Den första purpurin "rospurpurin" dansades endast av brudparet och pällhållarna d.v.s marskalkar och tärnor. Den inleddes med en polonäs som kallades "roson". Turerna var många och invecklade. Säkert svettades - såsom Slotte säger - arbetsnävarna. Och varje felsteg noterades av åskådarna och förstorades ytterligare av att det syntes i alla speglar som hängde kring väggarna: "Herre jemine, den dumheten syns uti trettio speglar." 
Också i "Skymningsdansen" skildras bröllopspurpuriet, som går i brudstugan. Bröllopsdansen pågick i flera dagar. Varje purpuri tog flera timmar i anspråk, tiden varierade beroende på gästernas antal. Dansen kunde avbrytas för mat och kaffe. Ju längre bröllopet framskred dess muntrare och högljuddare blev dansen: "pojkarna stiga starkt med kraftiga ben" och luggarna slänga "stolt som kämpamanar".

De gamlas hälsning till brudparet "Men liljorna de växa upp om våren" är skriven till en skålmarsch, "plägarmarsch", som hämtats ur traditionen i Sundom utanför Vasa. Den spelades medan brudparet drack gästerna till. Bruden och brudgummen satt då på det långa bordet som stod längs stugans framvägg. Var och en av gästerna trädde fram, bjöds på en sup brännvin och en bit ost. Såsom många skålmarscher hade också denna en text, som under ceremonin sjöngs av gästerna:

Det kommer en skål ifrån brudeparets hand, och den som vill dricka han stige då fram.

Och därför så dricka vi och hålla oss så glad, och ängslan och sorgen försvinna.

Ceremonin var mycket högtidlig och det hände inte sällan att en och annan brast i gråt. Otto Andersson uppger, att det skall ha inträffat, att sången drunknat i gråten och snyftningarna. Vid något tillfälle skall man t.o.m. ha varit tvungen att bära bort den av rörelse anfäktade. Andersson tecknade upp melodin sommaren 1903 efter den 70-årige spelmannen Otto Petander i Sundom (Andersson 1969, 16). Ännu på 1940-talet sjöngs denna avskedsskål vid bröllopen och jag har även spelat in den på band vid ett flertal tillfällen.

Helt följdriktigt avslutas bröllopssviten med en "Slutmarsch". När de tre bröllopsdagarna var till ända och värdarna ansåg att festligheterna kunde avslutas kallade de på spelmännen som stämde upp slutmarschen. Då förstod var och en att tacka för sig och bege sig hemåt. Då förplägnaden varit god och gästerna fått sig en och annan styrketår hände det ofta att det blev kappkörning under hemfärden.

Far är i körartag

efter de goda och ymniga bägarna.

Brunte han ger ett slag,

låter det gå som en vind utåt vägarna.

Gubben har huvudet tappat, men moran i tömmarna tar.

Mor hon har hufvud och skinn uppå näsan för son och för far.

Melodin är en gammal brudmarsch som 1905 spelades för Otto Andersson av Alfred Nyberg i Pedersöre, Kållby. 


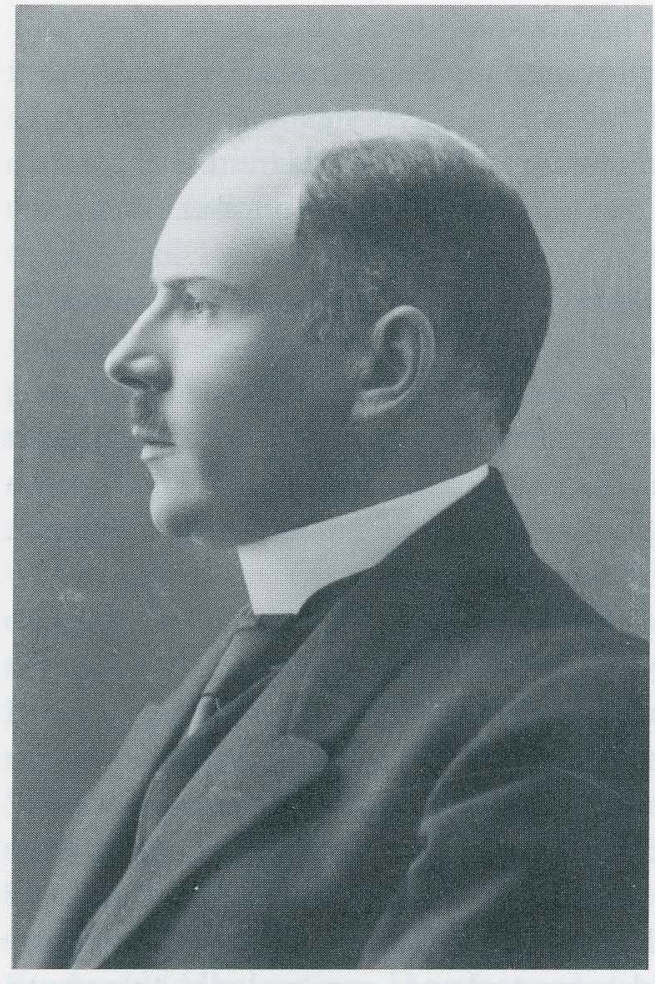

Ernst V. Knape 1873-1929.

Museiverket.

Knapes produktion inom denna genre är inte lika omfattande som Slottes. En fräsch hembygdsromantik finner vi i hans "Sommarmarsch", som med sin sprittande durton vandrat rakt in i finlandssvenska sångares hjärtan. Den är skriven till en hurtig brudmarsch spelad av Vöråspelmannen Fredrik Berg "Sepp-Fredrik" (f.1848) och upptecknad av Otto Andersson 1905. När Otto Andersson först tog emot Knapes text förvånades han över diktens form. Knape hade nämligen versifierat dikten på följande sätt:

Över bygden

skiner sol i blånande sky.

Och när sunnan

kring fälten dansar,

klöverns kransar sprider

sin sommardoft

till alla loft

i grönklädd by etc. 
Formen verkade i någon mån förvirrande med sina korta versrader. Men när jag skrev ut dem under melodin och sjöng denna vid pianot, fann jag dem fyllda av en betagande sommarstämning och på ett lyckligt sätt sammansmälta med den mjuka, vågiga marschmelodin. Och när de båda skalderna senare träffades hemma hos mig, var vi alla tre eniga om, att Knape här löst sin uppgift på ett utmärkt sätt (Andersson 1969, s. 17).

I ett flertal av Knapes dikter finner vi ett drag av vemod, vekhet och dröm. Älskad i högtidligare sammanhang har "Var är vägens mål" blivit, skriven till en mollbetonad, vemodig polskemelodi spelad av Johan Erik Johansson Sebbas (f. 1846) i Petalax. Den har främst framförts som solosång till pianoackompanjemang, men reciteras i dag gärna ofta med tillhörande polskemelodi ljudande i bakgrunden. Första strofens senare del citeras gärna i minnesrunor och dödsannonser:

Långt bortom älv och slätt och skog och strand

ligger lyckans alltid solbelysta land.

Där är vägens mål, och där är vilans bo, och ro är där visst för all vår längtan.

Vemodig är också Knapes text "Ant han dansa med mig" till en polskemelodi som användes som penningdans vid bröllop i Gamlakarlebytrakten. Otto Andersson tecknade upp den efter Leander Honga (f. 1837). Den inleddes med pizzicato ("sprättande") vilket givit den benämningen "Sprättandansen". Melodin åtföljdes av följande textfragment:

Ant han dansa med mej

Matt han dansa med mej

Jock han sjuffa mej i "rågen" (vrån).

Utgående från dessa rader diktade Knape sin känsliga dikt. I dikten "Kväll vid myren" till en polska från Jeppo, tolkas den övergivnas smärta i annan tonart. En stark lokalstämning vilar över denna som över många andra av Knapes dikter. Grundtonen är den förtvivlades inåtvända smärta:

Aldrig mer han kommer

förr så redobogen.

Natten är inne och mörkt på myr och i skogen. 


\section{Musiken}

Det var i allmänhet Otto Andersson som bland melodiuppteckningarna valde ut melodier som man lämpligen skulle kunna skriva text till.

Snart hade jag en nätt samling som i mitt tycke var representativ för vår folkmusik både i rytmiskt och melodiskt avseende. Dessutom var dessa melodier sångbara och borde kunna arrangeras för både solosång och körsång. För framförandet hade jag föreningen Brages sångkör till mitt förfogande; kören behövde tillökning till sin repertoar, och jag var redan nu hemmastadd i att arrangera folkmelodier ... (Andersson 1969, 14).

De melodier Otto Andersson valde ut var i huvudsak österbottniska spelmanslåtar. Det var melodier som en lång tid levat i traditionen, som älskats och uppskattats av spelmän, sångare, dansare och lyssnare i generationer. Bland dessa valde Otto Andersson ut de som han ansåg vackrast, de som hade en tilltalande melodi, som var sångbara och lämpade sig för ett eventuellt körarrangemang. Många av dessa melodier hade folklig anknytning till bröllop. Bröllopen var ju de största folkliga festerna och en rik melodiflora av högtidlig karaktär hade knutits till dem. Till sitt förfogande hade Otto Andersson flera hundra upptecknade melodier bland vilka han kunde välja de bästa. Det är således inte förvånande att melodierna slog an och gav texterna lyft och stadga. I allmänhet var han tvungen att i någon mån förenkla spelmansmelodierna, för att de skulle lämpa sig för sång. T.ex. när det gällde den framstående Petalaxspelmannen Johan Erik Johansson Sebbas konstfulla polska var han tvungen att utesluta en hel del genomgångs- och växeltoner för att få en sångbar melodi till "Var är vägens mål". Överlag blev spelmansmelodierna genom textsättningen och arrangemangen enklare, långsammare och högtidligare. Detta kommer väl till synes även i "Jungfrun träder fram på riddarsalens golv". Även om körsatsen här är ovanligt detaljerat utarbetad har musiken i arrangemanget en helt annan karaktär är den menuett som i dag lever kvar bland spelmännen i Oravais, Jeppo och Munsala. Texten och arrangemanget har givit melodin en högtidlig, nästan pompös prägel, medan spelmännen framför menuetten livligt, snabbt, lätt och framförallt dansbart, med en mängd övergångstoner och en folklig sekundstämma. I spelmanstraditionen existerar den därtill i två olika former, en moll-och en durvariant, som ofta kombineras och ger en intressant kontrastverkan.

Som arrangör kan Otto Andersson betecknas som rätt konservativ. Stilistiskt tillhör hans arrangemang den senromantiska linjen. Han följde den tradition som utformats av Martin Wegelius, Karl Ekman och andra tidiga arrangörer inom den tidiga finlandssvenska musikrörelsen. Detta hindrade emellertid inte Andersson att 
ställa sig kritisk till en del av Wegelius körarrangemang. Otto Andersson ansåg dem alltför svåra genom sin polyfoni.

Dessutom hade jag smittats av den uppfattningen, som företräddes av vissa tyska och österrikiska visarrangörer, nämligen att folkvisorna löpte fara att förlora sin prägel, om de kläddes i en alltför rik harmonisk skrud (Andersson 1947,128$)$.

Otto Andersson uppger att Wegelius ofta diskuterat arrangeringsprinciper med sina elever. Wegelius uppfattning var att det är arrangörens skyldighet att försköna melodierna på bästa konstnärliga sätt och $\mathrm{i}$ bearbetningen ingjuta så mycken skönhet som möjligt. "Framför allt låg det honom om hjärtat, att den musik som gavs åt folket skulle vara lödig och fylla äkta konstnärliga krav" (Andersson 1947, 128).

Otto Andersson bibehöll ett vokalt och textnära skrivsätt hela tiden. ”Jag följde mina principer" (Andersson 1947, 128). Han arrangerade ett sextiotal folkvisor, de flesta av dem publicerade av Brage och uruppförda av dess kör. Arrangemangen till de nya dikterna skiljer sig inte från Otto Anderssons folkvisearrangemang i övrigt. Harmonivalet var konventionellt, stämföringen naturlig och den bärande melodin framträder alltid tydligt, detsamma gäller texten som förs fram på ett logiskt - man kunde säga folkligt - sätt. Allt detta gjorde arrangemangen omtyckta; också landsbygdskörerna - som inte alltid var så musikaliskt drillade - kunde utan svårighet behärska Otto Anderssons arrangemang. 1947 konstaterade Andersson att han med tiden kommit att alltmer närma sig Wegelius sätt att arbeta:

- - - jag har aldrig upphört att beundra Wegelius’ mästerliga körsatser, och i mina senare arrangemang har jag stundom kommit att närma mig hans stil. Men jag gör alltjämt skillnad på arrangemang och bearbetningar, och jag anser, att även de förra ha sitt konstnärliga berättigande, t.o.m. i den enklaste homofona form (Andersson 1947, 128).

Som arrangör av folkliga melodier för blandad kör är Otto Andersson fortfarande oöverträffad vad gäller popularitet hos sångare och publik - låt vara att en del musikkritiker ansett arrangemangen alltför "traditionella" och "jämntjocka".

Att dikta texter till folkmelodier kräver stor musikalitet. Såväl Slotte som Knape var omvittnat musikaliska. Otto Andersson skriver om Slotte 1927:

Bäst har han avlyssnat och förklarat tonerna till de gamla visor och låtar, vilka ända från barndomstiden ljudit för hans öra. Hans förmåga att i dikten finna en motsvarande form för melodien var ofta rent av häpnadsväckande. Orden liksom smekes av melodiens tonfall. Många av hans ordsätt- 
ningar sluta sig så intimt till melodiens rytm och tongångar, att man snarast tror, att dikt och melodi samtidigt uppstått (Andersson 1927).

I dag, när folkmusiken på nytt åtnjuter stor popularitet, har många yngre musiker inspirerats till att arrangera folkmusikmaterial med tanke på framförande i kör och orkester. Intressant i detta sammanhang är att notera att flera arrangörer valt att utgå - inte från uppteckningarna - utan från Otto Anderssons bearbetningar av de folkliga melodierna. M.a.o. betraktas Otto Anderssons bearbetade version av en folklig melodi som den traditionella. I synnerhet "Bragevisorna" med texter av Slotte och Knape har under det senaste decenniet framförts av blandade körer och manskörer i nyarrangemang, vilka tacksamt mottagits av såväl musikkritiker som konsertpublik.

\section{Mottagandet}

Utan överdrift kan man säga att den nya sånggenren blev en verklig fullträff. Vartefter sångerna presenterades blev de succé, - det finns knappast något undantag från den regeln. "Över bygden" t.ex. fick sitt elddop vid den rikssvenska och finlandssvenska ungdomens sommarmöte i Visby 1913, där den sjöngs både vid framträdanden för publik och vid vandringar genom stadens gator. Otto Andersson beskriver mottagandet: "Jag har aldrig kunnat glömma den entusiasm, med vilken den mottogs av allmänheten, som i stora skockar följde Brages kör var den gick fram och krävde marschen om och om utan återvändo" (Andersson 1969, 17).

I en särställning när det gäller folklig förankring står helt naturligt "Slumrande toner". I mer än åtta decennier har den ljudit som körsång och unison avslutningssång vid olika festtillfällen runtom i svenskbygderna. Den har blivit den sång som fått tolka kärleken till kulturarv och hembygd. Den har vid sidan av "Modersmålets sång" blivit ett slags finlandssvensk nationalsång och numera reser sig publiken när den sjungs. Den har översatts till finska och sjunges mycket även i Sverige. Oerhört stor betydelse som en länk till hemlandet har den fătt bland de finlandssvenska emigranterna i Amerika.

Alexander Slotte blev redan under sin livstid föremål för tacksam hyllning med anledning av sin diktning, men först och främst som "Slumrande toners skald". När hans samlade dikter Sånger och Syner utkom till julen 1918, följde Brage påpassligt upp framgången med en Slotteafton på Svenska Teatern i Helsingfors valborgsmässoaftonen 1919. Salongen var slutsåld trots förhöjda priser. Hbl skriver:

I går, på den i folktraditionen så betydelsefulla Valborgsmässoaftonen, hade föreningen Brage på Svenska Teatern föranstaltat ett festuppträdande 
till ära för en av sina mest framskjutna och betydande medlemmar. Hyllningen gällde skalden Alexander Slotte vars hela verksamhet ägnats de ideal föreningen Brage gjort till sina och vars rika poetiska alstring i första hand kommit Brage och sedan genom den hela svenskfolket i Finland till godo. Redan länge ha ju Slotte-sångerna intagit en synnerligen betydande plats på Brages program och den sång, som icke blott blivit Brages lystringssång utan överallt i det svenska Finland sjunges på ett alldeles speciellt sätt, med en egen stämning och värme -"Slumrande toner" - är en av Slottes skänker till Brage och alla dem, som känna styrkan hos de band, vilka knyta samman nutid med forntid, alla dem, som vilja vårda fädernearvet i språk och kultur (Hbl 1.5.1919).

Slottes sånger framfördes dels av Brages sångkör, dels som solosång. Programmet upptog bl.a. fyra satser ur "Bröllopssvit" av vilka "Rosan" bisserades. "Jungfrun träder fram på riddarsalens golv" gavs som tablå. Hufvudstadsbladet skriver:

Uti iscensättning av författaren själv och i sångarrangemang av Otto Andersson framfördes så tablån "Jungfrun träder fram på riddarsalens golv" ett av programmets verkningsfullaste nummer. Bakom en tyllridå sågs bröllopsfesten med brud och brudgum, tärnor och ungersvenner i färgrika dräkter trådande dans i riddarsalen - en bild som gav stark medeltids- och balladstämning, yttermera förhöjd genom sångackompanjemang av Bragekören på scenen. Den vackra tablån apploderades starkt och publiken hade ingenting hällre önskat än att också den kunnat ännu en gång förevisas" (Hbl 1.5 1919).

Den ideologiska laddning som är förknippad med "Slumrande toner" har medfört att just den sången under årtiondenas lopp utsatts för angrepp från olika håll. Otto Andersson, som för sin folkkulturella verksamhet tidtals fått utstå hård kritik från kulturelitens sida, förmodade 1969 att angreppens tid då var förbi:

Under ett skede - 1940-talet - blev sången föremål för angrepp från en ung falang, som på 40-talet vände sig mot den folkliga kulturverksamheten. Man talade om "slumrande-toner-mentaliteten", som borde hindras att utbreda sig. Men dessa angrepp har nu för länge sedan förlorat sin kraft (Andersson 1969, 18).

Men angreppen har fortsatt. Erik Geber - ung körledare på 1970-talet - såg "Slumrande toner" som ett hinder för nyrekryteringen av unga sångare: 


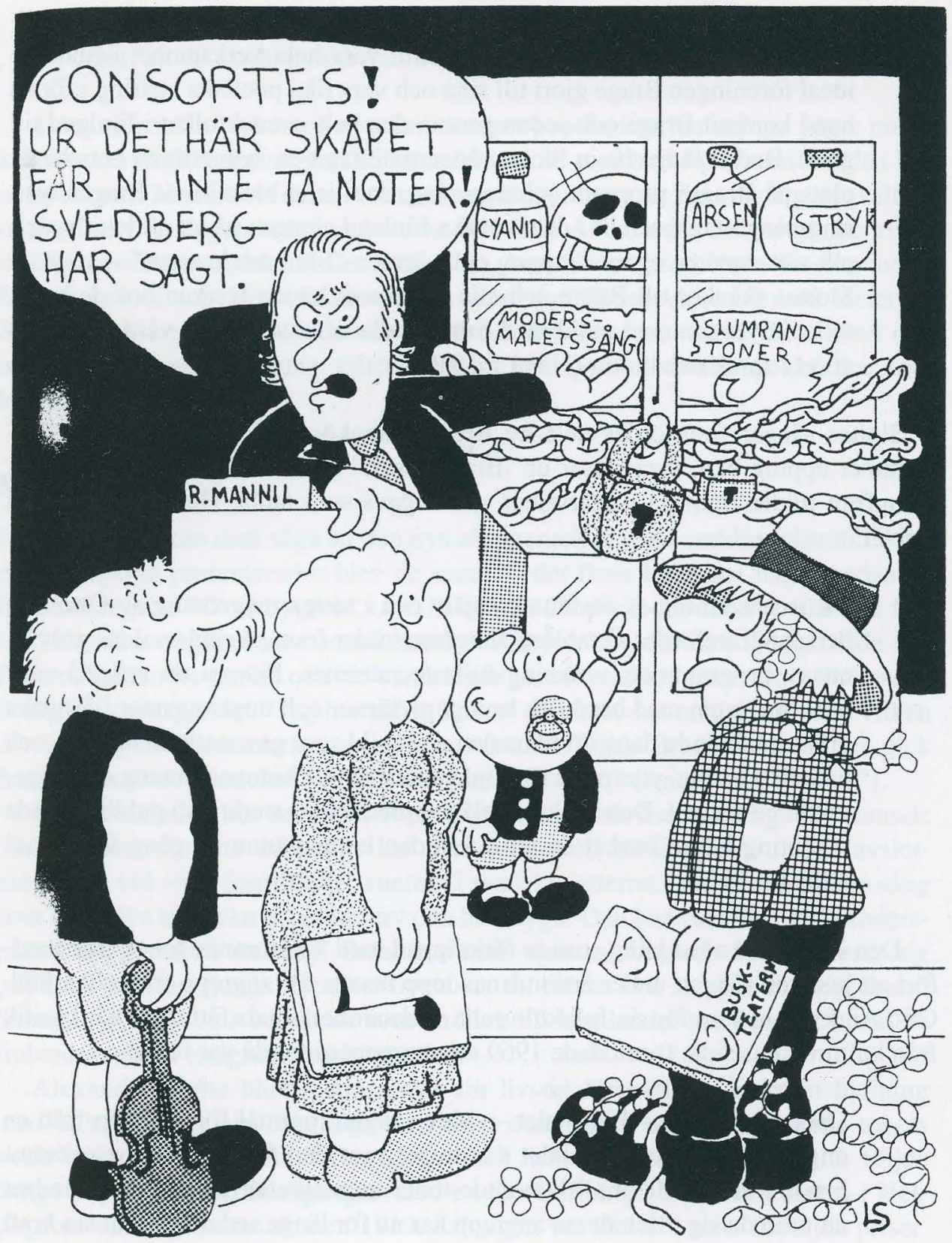

"Ragnar Mannil et consortes...". Leif Sjöströms illustration till Ralf Norrmans artikel "Slumrande toner" $i$ Horisont 5-6.1982. 
Utan att i detalj gå in på repertoarproblemet, skall jag uttrycka som min personliga åsikt, att repertoaren bör vara öppen för vad som rör sig i tiden och framförallt omväxlande ...

Huvudsaken är att man inte år efter år på de äldres begäran tjatar på med samma "slumrande toner"... (Geber 1972, 120).

När Gustaf Widén, redaktör på Borgåbladet, i november 1981 anmälde Lars Sandbackas monografi över Alexander Slotte, inledde han sin anmälan på följande sätt:

Det har alltid förefallit mej en smula löjeväckande att den finlandssvenska musikkulturens signaturmelodi heter "Slumrande toner". Länge var det ju onekligen så att de traditionella sångfesterna tycktes helt fastlåsta vid konservativa ideal, att man slumrade in till tonerna av en självgodhetens höga visa.

Börjar man granska texten ter den sej onekligen pekoralistisk: "Slumrande toner, fjärran ur tiden,/ toner ifrån stugor, från fält och vänan lid,/ sällsamma röster ur gravarnas dunkel, jubel och kvalsång från hänsovnas strid”. Som lyrik är det närmast parodiskt, trots att orden genom traditionens makt fått högre dignitet (Bbl 17.11.1981).

Hösten 1982 behandlar Nya Argus huvudredaktör Ingmar Svedberg i sin ledare den gångna sommarens kulturevenemang och skriver bl.a.:

Ragnar Mannil et consortes har uppvaktat vid någons grav och därmed allt. Visst är det skönt att få sjunga Slumrande toner och Modersmålets sång på hembygdsfester och njuta av den finlandssvenska småskaligheten och gemenskapen, men måste det folkloristiska och musealt tillbakablickande så dominera våra kulturevenemang? (Svedberg 1982, 135).

Detta föranledde Ralf Norrman att i Horisont bemöta Svedberg:

Det är inte första gången som "Slumrande toner" används som en symbol för det mest förhatliga som kan tänkas. Visan har länge varit en skottavla bland finlandssvenska självhatare (Norrman 1982, 28).

Enligt honom uppmanar sången oss till följsamhet mot det existerande och att utveckla det egna. Detta förklarar, hävdar han, varför visan blivit så omstridd. 
Kontinuitet, organiskt fortlevande kultur och etniskt självförtroende har varit idealen för den folkliga konsten. I Helsingfors har däremot avantgardism, modernism, kosmopolitanism och experimentlusta varit idealen, och existerande lokala traditioner har betraktats som en barlast.

Många tiotalstusen finlandssvenskar har otaliga gånger sjungit "Slumrande toner" och känt sig styrkta av dess budskap. Fastän problemen skulle vara många, fastän förfallet eller försummelsen skulle vara stor, så är skadan inte omöjlig att reparera; en upprättelse är ännu möjlig. Fastän kolen skulle vara slocknade på härden, så kan vi blåsa nytt liv i dem igen, och återupprätta vårt hem här i världen (Norrman 1982, 28-30).

Han fortsätter diskussionen genom att betona skillnader mellan huvudstad och landsbygd, mellan elitism och folklighet. Han hänvisar till polariteter som konsumtion-produktion, upplösning-kontinuitet, skam-stolthet, kosmopolitism-lokalitet (hembygd, hemland) och konstaterar till slut:

"Slumrande toner" var från första början ett uttryck för en kämpande folklig, finlandssvensk radikalism, och sådan har den också förblivit, även om tiden gjort att endel drag i visan numera kan verka ålderdomliga. Visans budskap är knappast mindre aktuellt idag än det var då den skrevs (Norrman 1982, 31).

En diktning, som sju decennier efter sin tillkomst kan väcka sådan debatt, är ingen obetydlig diktning - vilket man lätt kan förledas att tro när man läser litteraturhistoriska översikter där den med en axelryckning avfärdas som hembygdsromantik. Angreppen på "Slumrande toner" visar den stora betydelse sången tillskrivits. Sången sjöngs vid kollektiva samlingstillfällen där man i festtal och festdikter betonade gemenskapen i historia, språk och kultur. Den blev en del av en kult (Jfr. Anderson 1983, 132).

Text, musik, ideologisk laddning och uppförandesituation - allt detta sammantaget bidrog till att ge "bragevisorna" en särställning i finlandssvenskt kulturliv (Jfr Karlsson 1988, 242). Sångerna blev symboler man samlades kring. De slog broar mellan samhällsklasser och regioner. Med hjälp av dem kunde finlandssvenskarna bygga upp en identitet som grupp. Den nationalromantiska sånggenre, som med folkvisan som förebild skapades under 1900-talets andra decennium, kom att som identitetsskapare få långt större betydelse än de egentliga folkvisorna. 


\section{Källor och litteratur:}

ANDERSON, Benedict, 1983. Imagined communities. Reflections on the origin and spread of nationalism. London.

ANDERSSON, Otto, 1927. Alexander Slotte. Minnesruna i Budkavlen nr 3. 1927. Sign. O.A. Åbo.

ANDERSSON, Otto, 1947. Finlandssvenska musikfester under 50 år. Åbo.

ANDERSSON, Otto, 1967. Finländsk folklore. Tidig kalevalaforskning. Finlandssvensk insamlingsverksamhet. Åbo. Även som: Skrifter utg. av SVA 4. Stockholm.

ANDERSSON, Otto, 1969. När spelmanslåten blev dikt. Budkavlen 1969-1970 (utg. Sven Andersson). Åbo 1971.

Borgåbladet (Bbl) 17.11.1981.

Brages Urklippsverk (BrU), mapparna 633 och 1125.

Brages Årsskrift (BrÅ) 1907, 1909, 1910

BRUHN, Karl, 1929. Hembygdens sångare. [Minnesruna över Ernst. V. Knape]. Kalender utg. av Svenska folkskolans vänner 1929. Helsingfors.

DAHLSTRÖM, Fabian, 1971. Otto Andersson. Fin kultur och folklig. Finländska gestalter IX. Ekenäs 1971.

DAHLSTRÖM, Fabian, 1991. Musikaliska strömningar i Finland före 1891. Musik-Sång-Fest 1891-1991. De finlandssvenska sångfesterna som kulturföreteelse och impulsgivare. Finlands Svenska Sång och Musikförbund 1991.

FORSLIN, Alfhild, 1970. Några synpunkter på folkvistraditionen i Svenskfinland. Budkavlen 1968. Åbo 1970.

GEBER, Erik, 1972. Nyrekryteringen till våra blandade körer. Åbolands sång och musikförbund 1922-1972. Festskrift (red. P. Jansson). Åbo.

Hufvudstadsbladet (Hbl) 17.3.1916; 1.5.1919.

HULDÉN, Lars, 1990. Slumrande toner. En finlandssvensk nationalromantisk hymn. Inte bara visor. Studier kring folklig diktning och musik tillägnade Bengt R. Jonsson den 19 mars 1990. Skrifter utgivna av Svenskt visarkiv 11. Stockholm.

Kalender utgiven av Svenska folkskolans vänner (SFV Kal.) 1899, 1927 och 1929. Helsingfors.

KARLSSON, Henrik, 1988. "O, ädle svensk!" Biskop Thomas'frihetssång i musik och politik. Kungl. Musikaliska akademiens skriftserie nr 59. Skrifter från Musikvetenskapliga institutionen i Göteborg $\mathrm{nr}$ 19. Stockholm.

KUMMEL, Bengt, 1994. Svenskar i all världen förenen eder! Vilhelm Lundström och den allsvenska rörelsen. Åbo. 
Nyländska folkvisor I-II. Nyland III och V. Red. Ernst Lagus. Helsingfors 1887 och 1893-1900.

LÖNNQVIST, Bo, 1983. Folkkulturen i svenskhetens tjänst. Aspekter på sambandet mellan etnisk mobilisation och kulturell värdeorientering. Svenskt i Finland 1. Skrifter utg. av Svenska litteratursällskapet i Finland nr 511. Helsingfors.

NORRMAN, Ralf, 1982. Slumrande toner. Horisont 5-6. 1982.

RUNDT, Joel, 1927. Alexander Slotte. [Minnesruna undertecknad J. Rdt.]. Kalender utg. av Svenska folkskolans vänner. Helsingfors.

SANDBACKA, Lars, 1981. Alexander Slotte - Slumrande toners skald. Helsingfors.

STRANDBERG, Einar, 1946. Alexander Slottes liv och diktning. BrA 19361945. 40 års festskrift. Helsingfors.

SVEDBERG, Ingmar, 1982. Finlandssvensk kultursommar? Nya Argus 910.1982.

TEIR, Henrik, 1996. Ernst V. Knape - läkaren och diktaren från Österbotten. Laboratorium för folk och kultur 1/1996. utg. Föreningen Brage i Helsingfors r.f.

The Types of the Scandinavian Medieval Ballad (TSB). A descriptive catalogue. Edit. Bengt R. Jonsson, Svale Solheim and Eva Danielson. In collaboration with Mortan Nolsoe and W. Edson Richmond. Oslo, Bergen, Tromso. 1978. Även som Skrifter utg. av Svenskt visarkiv. 5. Stockholm 1978.

Vasabladet (Vbl) 7.7.1921. 